\title{
砂の弾塑性構成式の締固め砂質地盤への適用
}

\author{
岡 二三生* 日 置 和 昭** \\ 小高猛 司* 山田裕 久***
}

\section{An Elasto-Plastic Constitutive Model for Sand and Its Application to Compacted Sandy Ground}

by

\author{
Fusao OKA ${ }^{*}$, Kazuaki HiokI ${ }^{* *}$, Takeshi KodAKA ${ }^{*}$ and Hirohisa YAMAdA ${ }^{* * *}$
}

\begin{abstract}
Sand compaction pile method is an effective soil improvement technique to prevent the liquefaction of loose sandy ground. Since the current design method of the sand compaction pile method is only incorporating the effect of the densification of sand due to compaction, the seismic design for this method has been reexamined after the 1995 Hyogoken Nambu Earthquake. However, the characteristics of compacted sand containing fine contents have not completely been clarified; it is difficult to incorporate all the complicated improvement effects to the current design code. In light of the recent trend of performance design, the dynamic numerical analyses by the finite element method have spread in practice. The soil water coupled liquefaction analysis, among many existing numerical analyses, can be particularly expected to evaluate the complicated improvement effects of compacted sand. Oka et al. have proposed the effective stress based liquefaction analysis using an elasto-plastic constitutive model for sand based on nonlinear kinematic hardening rule. In the present study, in order to explain the compaction effect of sand containing the fine contents, we have noted the relation between the parameters used in the elasto-plastic constitutive model and the state index of sand, Is. A series of undrained traixial compression tests of sand were conducted under the conditions that reproduce both the effective stress state and void ratio before and after compaction. We also simulated the triaxial test results by using the elasto-plastic constitutive model. It is found that the quasi overconsolidation ratio, $O C R^{*}$, is correlated to the state index of sand and is one of the key parameters to evaluate the compaction effect of sand.
\end{abstract}

Key words : Compaction effect of sand, Liquefaction, Elasto-plastic constitutive model for sand, State index of sand, Triaxial compression test, Numerical simulation

\section{1 はじめに}

ゆるい砂地盤は地震時に液状化の被害に遭遇する可能 性が高いが，それを防ぐ有効な対策工として，ゆるい砂 地盤内に密な砂杭を多数造成し複合地盤を形成する締固 め砂杭工法がある。別途用意した良質な砂を地盤深くま で投入するため，ケーシングパイプと呼ぶ鋼管を原地盤 に鉛直に貫入させ，さらにそのケーシングパイプを引き 抜く過程で静的あるいは動的に上下させながら投入した 良質な砂を締固めることにより，密な砂杭を造成する。 ケーシングパイプの貫入時と砂杭を締固めにより拡径す る過程で，砂杭周辺のゆるい砂地盤は強制的に横方向に 押し拡げられることにより，砂はゆる詰め構造から密詰 め構造へ変化する. それに伴い, 砂地盤の密度は増加し, せん断抵抗力も増加する. 自然状態の砂地盤の静止土圧 係数 $K_{0}$ （鉛直有効土圧に対する水平有効土圧の比）は概 ね 0.5 程度であるが，この砂杭拡径に伴う地盤の押し拡 げにより, この $K_{0}$ 值は大幅に上昇し, 有効応力が増加 することが報告されており , $^{1}$ そことも締固め砂杭改良
地盤の効果を高める一因と考えられる.

1995 年の兵庫県南部地震を契機として, 締固め改良地 盤の耐震性評価手法の見直しが行われつつあるが,2) 5) 細 粒分を含む砂の締固め時の密度増加量を正確に推定する ことも難しく, $N$ 值を主体とした現状設計法には, なお 課題が多い。一方, 性能設計が今後の主流となるのを背 景として, 有限要素法を用いた動的解析が広く一般的に 行われるようになってきた，その中でも，水一土骨格連 成場での砂地盤の地震時挙動を, 忠実に時間領域で計算 する有効応力液状化解析は今後の主役になると考えられ る.さらに, 有効応力液状化解析法を用いることにより, 改良地盤の有効応力状態の評価や, 剛性の高い締固め砂 杭が改良地盤内に混在する複合地盤効果についても評価 できることが期待されている.

岡 ${ }^{6)}$ は有効応力液状化解析法の開発を行い, さらに それに用いる砂の構成モデルの開発7)を行ってきた。そ の構成モデルは, 主に中密な砂の実験データに基づき構 築されており, 細粒分を含むゆるい砂への適用性の検討

原㭻受理 平成 14 年 10 月 30 日 Received Oct. 30, 2002

* 正 会 員 京都大学大学院工学研究科社会基盤工学専攻 ₹606-8501 京都市左京区吉田本町, Dept. of Civil and Earth Resources Eng., Kyoto Univ., Sakyo-ku, Kyoto, 606-8501

** 不動建設(森) ₹110-0016 東京都台東区台東, Fudo Construction Co., Ltd., Taito-ku, Tokyo, 110-0016

***大阪ガス㑣) †541-0046 大阪市中央区平野町, Osaka Gas Co., Ltd., Chuo-ku, Osaka, 541-0046 
が課題として残されてきた，本論文では，岡らによる弾 塑性構成式 7)を用いて, 細粒分を含む砂の締固め効果を 表現するために, 有効応力と密度との関係に着目しつつ, 関連する材料パラメータの決定を中心に検討を行う。平 均有効応力と密度から, 砂が現在おかれている状態を評

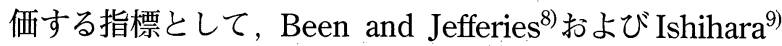
により, 状態変数 $\psi$ および状態指数 $I_{s}$ がそれぞれ提案さ れている。いずれの指標も, 広範な密度の砂を対象とし ており，しかも自然堆積した砂地盤であろうと，人工的 に締固められた砂地盤であろうと, 砂地盤の生成過程に よらず，定常状態の概念 ${ }^{10)}$ を通して，同じ指標で砂の状 態を評価することが可能である。そこで本論文では， $\psi$ および $I_{s}$ を砂の締固め度合いを定量的に評価する指標と して用いることとし, 岡らの弾塑性構成式の材料パラメ 一タと関連づけることを試みる。具体的には，締固め砂 杭の試験工事 ${ }^{1)}$ が実際に行われた千葉県佐原地区で採取 した佐原砂の非排水三軸試験を行うとともに，その試験 結果のシミュレーションを行い, 弾塑性構成式の材料パ ラメータと砂の状態変数および状態指数との関連を明ら かにしつつ, 締固め改良地盤への適用性を確認する.

\section{2 弾塑性構成モデルの締固め砂への適用}

\section{$2 \cdot 1$ 非線形移動硬化則に基づく弾塑性構成式 7)}

過去に受けた応力の履歴が現在の応力状態よりも大き い場合を過圧密状態と呼ぶ，過圧密状態にある砂がせん 断を受ける場合には，せん断初期には弾性挙動が卓越す る領域が存在する。そのため, 以下の式で定義される過 圧密境界面 ${ }^{11)}$ を導入する.

$$
f_{b}=\left\{\left(\eta_{i j}^{*}-\eta_{i j(0)}^{*}\right)\left(\eta_{i j}^{*}-\eta_{i j(0)}^{*}\right)\right\}^{\frac{1}{2}}+M_{m}^{*} \ln \frac{\sigma_{m}^{\prime}}{\sigma_{m b}^{\prime}}=0
$$

ここに, $\eta_{i j}^{*}=s_{i j} / \sigma_{m}^{\prime}, s_{i j}$ は偏差応力テンソル, $\sigma_{m}^{\prime}$ は平均 有効応力, $\eta_{i j(0)}^{*}$ は圧密終了時の $\eta_{i j}^{*}, M_{m}^{*}$ はせん断時に最 大体積圧縮ひずみが生じる变相時の応力比 $\eta^{*}=\left(\eta_{i j}^{*} \eta_{i j}^{*}\right)^{1 / 2}$ である．過圧密領域にある場合 $f_{b}<0$ となり，正規圧密 領域にある場合 $f_{b} \geq 0$ となる。 また， $\sigma_{m b}{ }^{\prime}$ は次式に従う。

$$
\sigma_{m b}^{\prime}=\sigma_{m b i}^{\prime} \exp \left(\frac{1+e_{0}}{\lambda-\kappa} v^{p}\right)
$$

ここに, $\sigma_{m b i}^{\prime}$ は $\sigma_{m b}^{\prime}$ の初期值であり, 圧密終了時の平均 有効応力 $\sigma_{m 0}^{\prime}$ に等しい. また， $e_{0}$ は初期間隙比， $v^{p}$ は塑

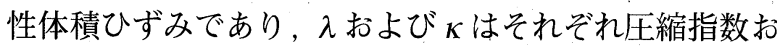
よび膨潤指数である. Fig. 1 に過圧密境界面 $f_{b}$ と以下に 示す塑性ポテンシャル面 $g$ 扎よび主要なパラメータとの 関係を示す.

降伏関数 $f$ および塑性ポテンシャル関数 $g$ は以下の式 で与える。

$$
f=g=\left\{\left(\eta_{i j}^{*}-\chi_{i j}^{*}\right)\left(\eta_{i j}^{*}-\chi_{i j}^{*}\right)\right\}^{\frac{1}{2}}+\bar{N}^{*}\left|\ln \left(\frac{\sigma_{m}^{\prime}}{\sigma_{m a}^{\prime}}\right)-y_{m}\right|=0
$$

ここに, $\sigma_{m a}^{\prime}$ は材料パラメータ, $\chi_{i j}{ }^{*}, y_{m}$ は非線形移動硬 化パラメータである。非関連流動則を用いる場合には， 降伏関数 $f$ は $\bar{N}^{*}=0$ とし，関連流動則を用いる場合には， $f, g$ ともに $\bar{N}^{*}=\widetilde{M}^{*}$ となる. $\bar{N}^{*}$ をロジスティッタ関数等で 制御することにより，せん断中に関連流動則から非関連

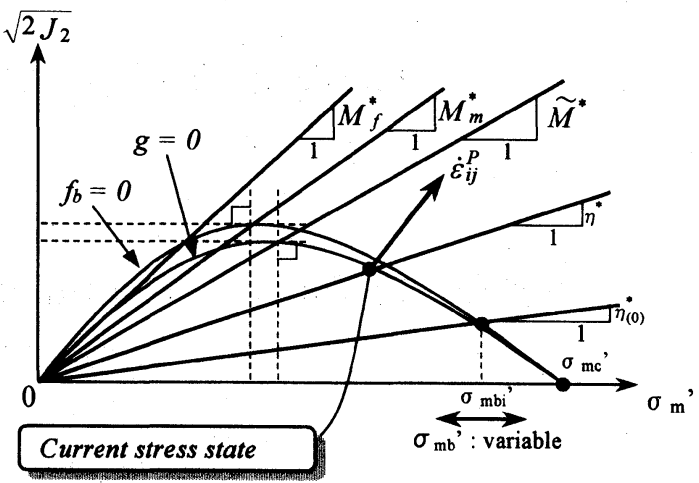

Fig. 1. Overconsolidation surface and plastic potential surface.

流動則に移すことも可能である。ただし，本論文では非 関連流動則 $\left(\bar{N}^{*}=0\right)$ を用いている．また， $\widetilde{M}^{*}$ は塑性ひず み増分の方向を規定するパラメータであり，以下のよう に決定される。

$$
\tilde{M}^{*}=-\frac{\eta^{*}}{\ln \left(\sigma_{m}^{\prime} / \sigma_{m c}^{\prime}\right)}\left(\text { 過圧密領域 }: f_{b}<0\right)
$$

$=M_{m}^{*}$ (正規圧密領域および $\widetilde{M}^{*}$ が $M_{m}^{*}$ に至った後 $)$ ここで， $\sigma_{m c}^{\prime}$ は過圧密境界面が $\sigma_{m}^{\prime}$ 軸と交差する時の值で あり, 次式となる.

$$
\sigma_{m c}^{\prime}=\sigma_{m b}^{\prime} \exp \left(\frac{\eta_{(0)}^{*}}{M_{m}^{*}}\right)
$$

一方, 式 (3)に含まれる非線形移動硬化パラメータ $\chi_{i j}{ }^{*}$ は $\eta_{i j}{ }^{*}$ に対応し, 塑性せん断ひずみ履歴を反映したせん断 硬化も表現するものであり，次式に従う。

$$
d \chi_{i j}^{*}=B^{*}\left(A^{*} d e_{i j}^{P}-\chi_{i j}^{*} d \gamma^{p^{*}}\right), d \gamma^{p^{*}}=\left(d e_{k l}^{P} d e_{k l}^{P}\right)^{1 / 2}
$$

ここに, $d e_{\mathrm{ij}}^{P}$ は塑性偏差ひずみ増分テンソルである. $A^{*}$, $B^{*}$ は材料パラメータであるが, 破壊応力比 $M_{f}^{*}$, および $\sigma_{m}^{\prime}$ で規準化された初期塑性せん断剛性 $G^{P}$ と以下のよう に関係づけられる。

$$
A^{*}=M_{f}^{*}, B^{*}=G^{P} / M_{f}^{*}
$$

さらに, $G^{P}$ は塑性せん断ひずみの蓄積により低下すると し，次式に従うものとする。

$$
G^{P}=\left(G_{\max }^{P}-G_{\min }^{P}\right) \exp \left(-C_{f} \gamma^{P^{*}}\right)+G_{\min }^{P}
$$

ここに, $G_{\text {max }}^{P}$ は $G^{P}$ の初期值, $G_{\text {min }}^{P}$ は $G^{P}$ の下限値, $C_{f}$ は $G^{P}$ の低下をコントロールする定数である.

塑性ポテンシャル関数 $g$ は応力空間上で凸曲面となる が, 負荷状態にある応力点 $\sigma_{i j}$ での塑性ひずみ増分 $d \varepsilon_{i j}$ の 方向と大きさは以下の一般化された流動則から決定さ れる。

$$
d \varepsilon_{i j}^{P}=H_{i j k l} \frac{\partial g}{\partial \sigma_{k l}}
$$

ここに, $H_{i j k l}$ は 4 階の等方テンソルであり, 自由度の 高いストレス・ダイレイタンシー関係を規定することが 可能であるが, 本論文では最も簡単な場合として, 非負 のスカラー量 $\Lambda$ を用いる。 この $\Lambda$ の大きさを求めるには 降伏関数 $f$ 全微分を用いた下式の適応条件式を適用 する。 
$d f=\frac{\partial f}{\partial \sigma_{i j}} d \sigma_{i j}+\frac{\partial f}{\partial \chi_{i j}^{*}} d \chi_{i j}^{*}=0$ (非関連流動則の場合)

すなわち, $d \sigma_{i j}$ を弾性剛性だけで表した $d \sigma_{i j}=D_{i j k l}^{E} d \varepsilon_{k l}^{E}=$ $D_{i j k l}^{E}\left(d \varepsilon_{k l}-d \varepsilon_{k l}^{P}\right)$ を式 (6)の $d \chi_{i j}{ }^{*}$ とともに式 (10)に代入 し，各塑性ひずみ増分に式 (9)の流動則を適用すること により $\Lambda$ が決定できる.

本論文では，非排水三軸圧縮試験のシミュレーション を行うが，非排水三軸条件での平均有効応力 $\sigma_{m}^{\prime}$ および 軸差応力 $q$ の増分は最終的に以下のようになる.

$$
\begin{aligned}
& d \sigma_{m}^{\prime}=K d \varepsilon_{k k}-\frac{\Lambda K}{\sigma_{m}^{\prime}}\left\{\tilde{M}^{*} \operatorname{sign}(B)-\frac{\eta_{s t}^{*}\left(\eta_{s t}^{*}-\chi_{s t}^{*}\right)}{\bar{\eta}_{x}^{*}}\right\} \\
& d q=2 \bar{\mu}\left(d \varepsilon_{11}-d \varepsilon_{33}\right)-\frac{2 \tilde{\mu} \Lambda}{\sigma_{m}^{\prime}}\left\{\frac{\left(\eta_{11}^{*}-\chi_{11}^{*}\right)-\left(\eta_{33}^{*}-\chi_{33}^{*}\right)}{\bar{\eta}_{x}^{*}}\right\}
\end{aligned}
$$

ここに, $\bar{\eta}_{x}^{*}=\left\{\left(\eta_{s t}^{*}-\chi_{s t}^{*}\right)\left(\eta_{s t}^{*}-\chi_{s t}^{*}\right)\right\}^{1 / 2}$ であり, $\operatorname{sign}(B)$ は $\ln \left\{\left(\sigma_{m}^{\prime} / \sigma_{m a}^{\prime}\right)-y_{m}\right\}$ の符号を表す。 また, $\tilde{\mu}$ はラメの定数， $K$ は体積弾性係数 $\left(=\left(1+e_{0}\right) \sigma_{m}^{\prime} / \kappa\right)$ である.

\section{$2 \cdot 2$ 密度変化に応じた砂の状態を表す指標}

砂の詰まり具合は間隙比 $e$ （砂粒子実質部分の体積に 対する空陌の体積の比率) で表され， $e$ が小さいほど密 詰めであり，大きいほどゆる詰めとなるが，細粒分の混 入率によっても $e$ 範囲は変動する。 また, 砂地盤形成 の履歴に応じても $e$ は異なり, 同じ砂でも同じ有効応力 状態で $e$ が異なることもあるうる。砂のような粒状材料 は $e$ の違いに応じてその挙動は異なるが，その異なり具 合を表す指標がいくつか提案されている，砂供試体を非 排水 (体積一定) 状態で三軸圧縮試験を行うと, 平均有 効応力 $\sigma_{m}^{\prime}$ もせん断応力も変化がないまま変形が進行す る定常状態 (Steady State) ${ }^{10)}$ に到達する。この定常状態 を連ねた定常状態線 (Steady State Line, SSL) は, 同じ砂 であれば Fig. 2 に示すように,$e \sim \log \sigma_{m}^{\prime}$ 空間内に 1 本 の直線として表される. Been and Jefferies ${ }^{8)}$ は定常状態 線を基準として, 状態変数 $\psi$ を用いて現在の砂の状態を 表現した. すなわち, 現在の砂の $e$ と同じ $\sigma_{m}^{\prime}$ での定常 状態における間隙比 $e_{s}$ の差を考え,

$$
\psi=e-e_{s}
$$

と状態変数 $\psi$ を定義し, 現在の砂が定常状態線の上側に あれば，下側にあれば $\psi<0$ となり， $\psi$ が大きいほど，
その砂は定常状態よりもゆる詰めの状態にあることを意 味し，流動性は高いと判断した。

一方, Ishihara ${ }^{9)}$ は非常にゆるい砂は一度ピーク強度を 示した後にひずみ軟化して定常状態にいたるが，通常の ゆるい砂は，ピーク強度を示してからひずみ軟化した後， 再びせん断強度が上昇してから定常状態に達することに 注目し，ひずみ軟化の最下点での $\sigma_{m}^{\prime}$ と $e$ の関係から疑 似定常状態 (Quasi Steady State) を提案した (Fig. 3). さ らに，状態指数 $I_{s}$ を次式のように定義した。

$$
I_{s}=\frac{e_{0}-e}{e_{0}-e_{s}}
$$

ここに, $e_{0}$ は現在の砂と同じ $\sigma_{m}^{\prime}$ において存在できる最 大の間隙比であり， $e_{s}$ は同じ $\sigma_{m}^{\prime} に$ におる準定常状態の

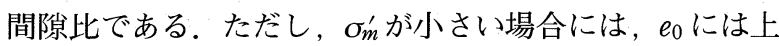
限值が存在し，ある程度 $\sigma_{m}^{\prime}$ が大きくなると， $e_{0}$ は超ゆ る詰め砂の等方圧縮曲線 (ICL) に従うものとしている. $I_{s}$ の定義より， $I_{s}$ がゼロに近いほど $e$ は大きく，流動性 が高く, $I_{s}$ が大きくなるほど $e$ は小さくなり流動性は低 いと判断される.

\section{$2 \cdot 3$ 状態指数と材料パラメータとの関連}

まずはじめに， Ishihara ${ }^{9)} に よ る$ 状態指数 $I_{s}$ を用いて， ゆるい砂から密な砂までの挙動を表すことを考える．非 常にゆるい砂は破壊に至るまでに塑性圧縮のみ生じ，逆 に密な砂はせん断初期に変相線を越えて塑性膨張に転じ る。したがって, $I_{s}$ が大きな密な砂は, 破壊応力比 $M_{f}^{*}$ と変相応力比 $M_{m}^{*}$ との差 $\Delta M$ が大きく, 逆に $I_{s}$ が小さい ゆるい砂は $\Delta M$ が小さくなる。 これを，材料定数 $\alpha, m$ を用いた次式で表すこととする。

$$
\Delta M=\alpha\left(I_{s}\right)^{m}, \quad \Delta M=M_{f}^{*}-M_{m}^{*}
$$

一方, 状態変数 $\psi$ や状態指数 $I_{s}$ は, 定常状態や最も ゆるい状態（正規圧密状態）の中で，現在の砂の状態が どこに位置するのかを示す指標であるので，弾塑性構成 式の中では疑似過圧密比 $O C R^{*}\left(=\sigma_{m b}^{\prime} / \sigma_{m 0}^{\prime}\right)$ が比較的近い 性質を持つと考えられる。そのため, 本論文では $O C R^{*}$ と $I_{s}$ に以下の線形関係が成り立つものと仮定する.

$$
O C R^{*}=\alpha+\beta \cdot I_{s}
$$

ここに， $\alpha, \beta$ は材料パラメータである.

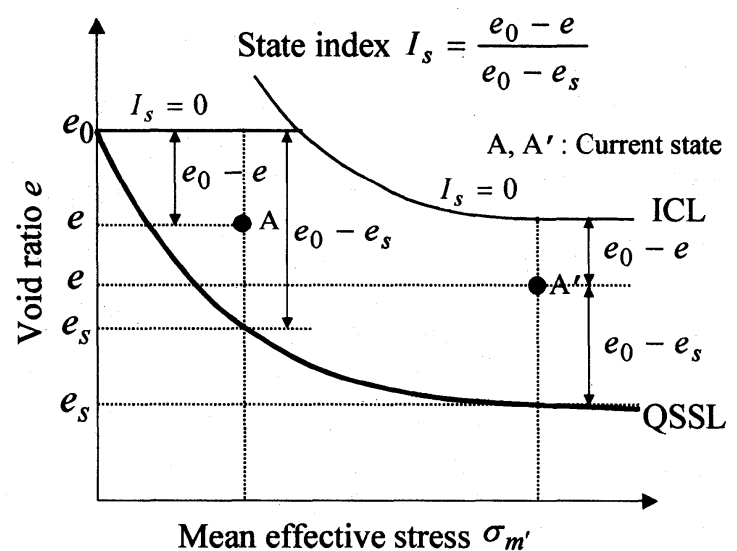

Fig. 3. Definition of state parameter $I_{s .}{ }^{9)}$

Fig. 2. Definition of state parameter $\psi^{8}$ ) 
以上で示した, 非線形移動硬化則に基づく弾塑性構成 式を用いて, 締固め前後の砂地盤の挙動を説明する場合 のパラメータの設定等について, 以下の三軸試験のシミュ レーションを通して考察する.

3 三軸圧縮試験とそのシミュレーション

\section{$3 \cdot 1$ 締固め砂杭工法による改良効果}

三軸試験の供試体は覮乱砂をモールドで突固めて作製 するが，その際に締固め砂杭工法の改良効果をどのよう に評価するかが重要となる。本論文では，千葉県佐原市 郊外で行われた締固め砂杭工法の試験工事 ${ }^{1)}$ の現場から 採取した佐原砂を使用した。この現場では，RI 密度検層， 孔内水平載荷試験（セルフボーリングタイプ）により， 締固め改良前後の砂地盤の連続的な密度分布や $K_{0}$ 値の 測定が行われている.1), 3)改良前後に打ける間隙比 $e$ と平 均有効応力 $\sigma_{m}^{\prime}$ の関係 (G. L. $-10.5 \mathrm{~m}$ 付近) を Fig. 4 に 示す. 置換率 (改良範囲の地盤平面に抢ける砂杭の面積 の割合） $a_{s}=10 \%, 20 \%$ となるにしたがい, 間隙比が減 少（密度増加）し， $K_{0}$ 值の増加により $\sigma_{m}^{\prime}$ が増加してい ることがわかる。

\section{$3 \cdot 2$ 佐原砂の特徵}

Table I に佐原砂の物性を示し, Fig. 5 に等方圧縮試 験結果を示す．豊浦砂のように粒子が堅固で細粒分を含 まない砂は， $\sigma_{m}^{\prime}$ の増加に伴う $e$ の減少量は無視できるほ ど小さいが, 試験に用いた佐原砂は細粒分含有率が比較

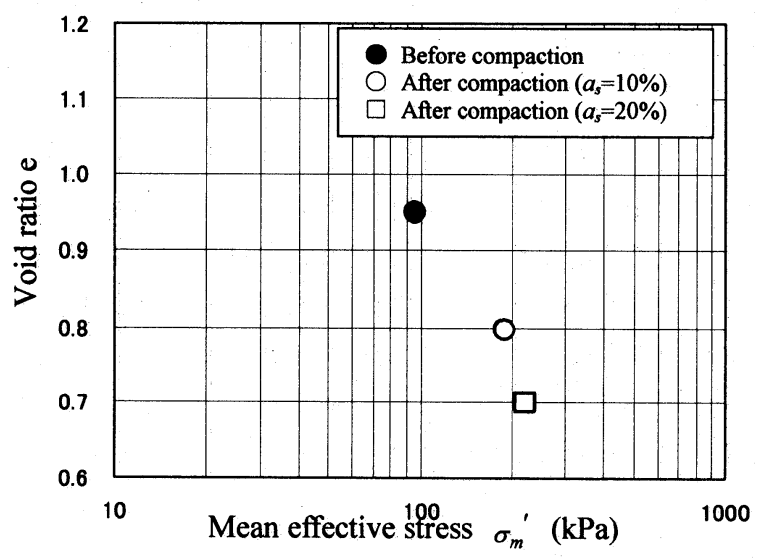

Fig. 4. $\sigma_{m}^{\prime} \sim e$ relation before and after compaction.

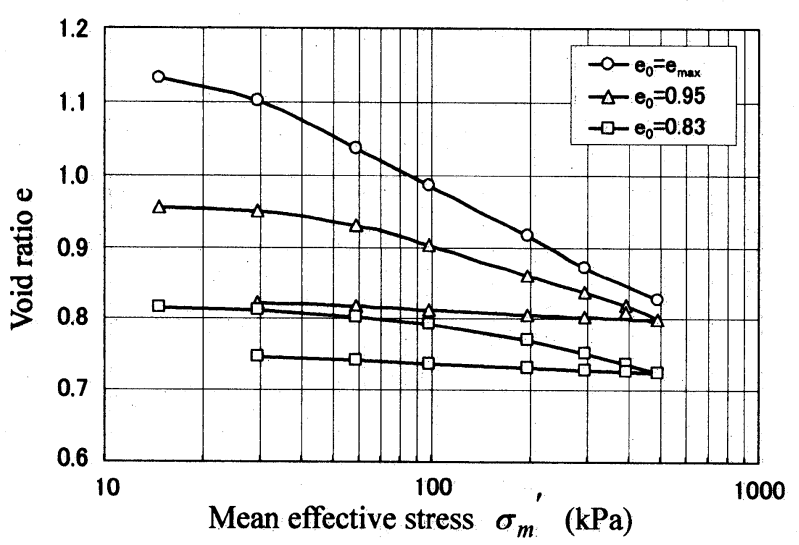

Fig. 5. Isotropic compression properties with various $e_{0}$.
Table I . Physical properties of Sawara sand.

\begin{tabular}{lc}
\hline Density of soil particle $\rho_{s}\left(\mathrm{~g} / \mathrm{cm}^{3}\right)$ & 2.763 \\
\hline Maximum void ratio $e_{\max }$ & 1.361 \\
\hline Minimum void ratio $e_{\min }$ & 0.864 \\
\hline Sand content $(75 \mu \mathrm{m}-2 \mathrm{~mm})(\%)$ & 86.1 \\
\hline Silt content $(2 \mu \mathrm{m}-75 \mu \mathrm{m})(\%)$ & 10.1 \\
\hline Clay content $(<2 \mu \mathrm{m})(\%)$ & 3.8 \\
\hline Mean grain size $D_{50}(\mathrm{~mm})$ & 0.2675 \\
\hline Uniformity coefficient $U_{c}$ & 8.06 \\
\hline Classification & Fine content mixed sand
\end{tabular}

的高いため, $\sigma_{m}^{\prime}$ の増加に伴う $e$ の減少が顕著に認められ る.なお，この圧縮試験は 3 種類の初期間隙比で行って いるが, $e_{0}=0.95$ および 0.83 の供試体は, Fig. 4 の改良 前および $a_{s}=10 \%$ の改良地盤を想定して作製したもので ある。

\section{$3 \cdot 3$ 三軸圧縮試験条件}

供試体は圧縮試験と同様に, 改良前地盤と $a_{s}=10 \%$ の改良地盤を想定して, 初期の目標間隙比が 0.95 および 0.80 となるよう, モールド内で突固めて作製した. Table II に非排水三軸圧縮試験の条件を示す．圧密応力はそれぞ れ 3 種類で行っているが, 改良前の $96(\mathrm{kPa})$, 改良後の $186(\mathrm{kPa})$ は，それぞれ Fig. 4 での現場試験で得られた $\sigma_{m}^{\prime}$ と等しくしたものである。なお，軸ひずみ $0.2 \% / \mathrm{min}$.で軸 ひずみ $30 \%$ まで非排水せん断を行った.

\section{$3 \cdot 4$ 試験結果とシミュレーション}

非排水三軸圧縮試験結果および非線形移動硬化則に基 づく弾塑性構成式を用いた数值シミュレーション結果を Fig. 6 およびFig. 7 に示す. 先述のように砂の $I_{s}$ に応じ て $M_{m}^{*}$ を変化させることにより, 広範な密度の砂の挙動 を表すことが可能であるが，本論文で用いた佐原砂の場 合, 間隙比の変化に伴う $M_{m}^{*}$ の変化が小さかったことか ら, 式 (15)の材料定数 $m$ を 0 とし， $\Delta M$ は一定とした。 ここでは, 擬似過圧密比 $O C R^{*}\left(=\sigma_{m b}^{\prime} / \sigma_{m 0}^{\prime}\right)$ に着目して数 值シミュレーションを実施した. Table III にシミュレーシ ヨンに用いた材料パラメータを示す。 $O C R^{*}$ および非線 形移動硬化パラメータ $\left(G_{\text {max }}^{P}, G_{\text {min }}^{P}, C_{f}\right)$ 以外のパラメ 一タは全て試験結果を基に設定した。 応力〜ひずみ関係 については, 変相線を越えてからの挙動がシミュレーシ ヨンと実験では多少異なり, 今後検討の余地があるが, 有効応力径路については, シミュレーションは試験結果 をよく説明している，応力〜ひずみ関係を十分に説明す

Table II . Test conditions.

\begin{tabular}{ccc}
\hline$e_{0}$ & $\sigma_{m 0}{ }^{\prime}(\mathrm{kPa})$ & Note \\
\hline 0.95 & $49,96,196$ & Before compaction \\
\hline 0.80 & $49,186,392$ & $\begin{array}{c}\text { After compaction } \\
\left(a_{s}=10 \%\right)\end{array}$ \\
\hline
\end{tabular}




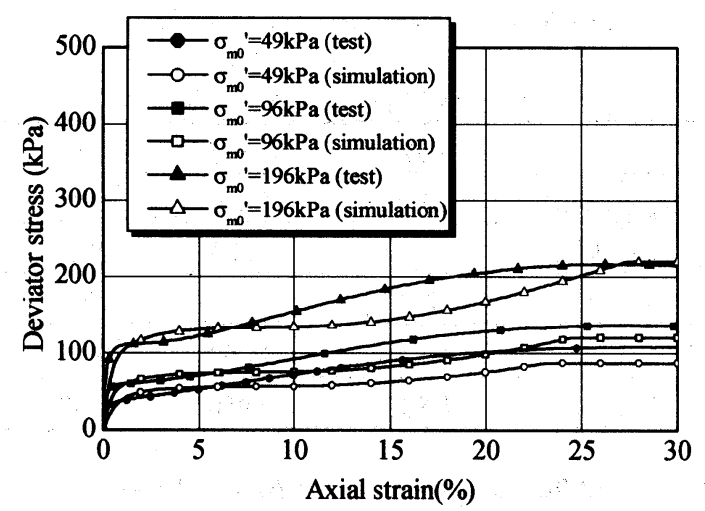

(a) Stress - strain relations

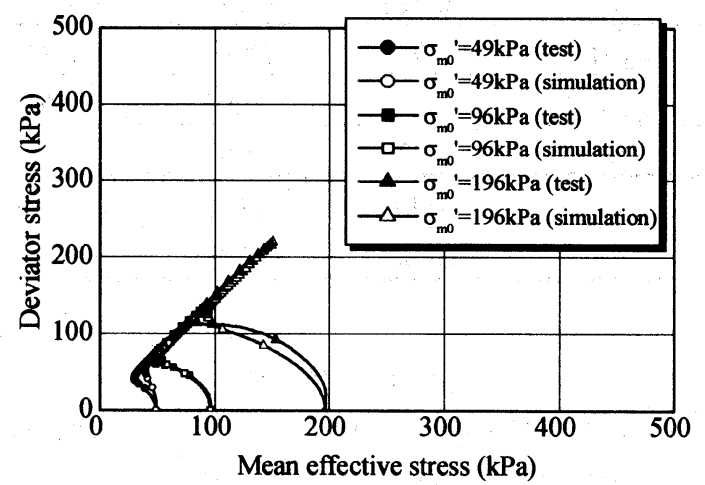

(b) Effective stress paths

Fig. 6. Results of Test and simulation. (before compaction)

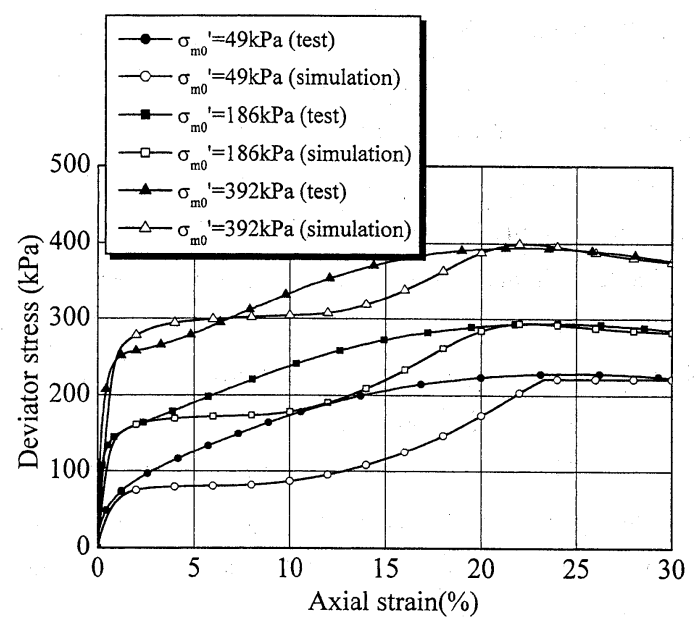

(a) Stress - strain relations

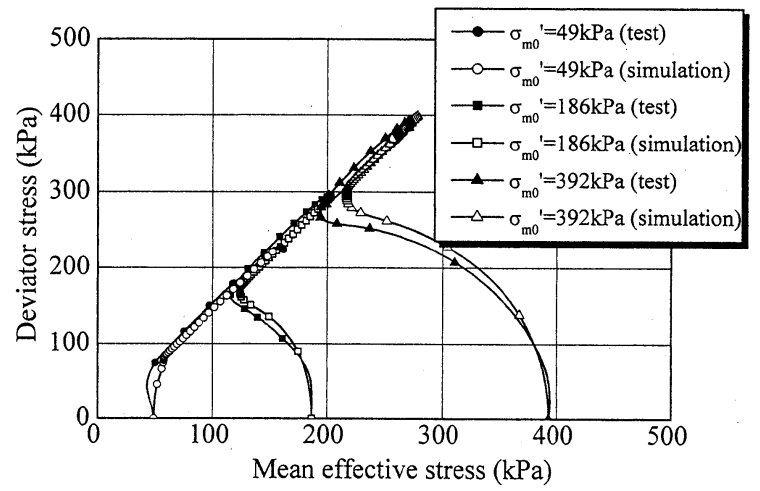

(b) Effective stress paths

Fig. 7. Results of Test and simulation. (after compaction)
るには非線形移動硬化パラメータについて若干の考察を 要すると考えられる. 次に, $O C R^{*}$ と状態变数 $\psi$ および 状態指数 $I_{s}$ との関係を，それでれ Fig. 8 および Fig. 9 に 示す。 また，各試験毎に算定した $\psi$ と $I_{s}$ を Table $\mathbb{N}$ に示 す. $\psi$ の算定には定常状態線 (SSL) が必要であり, $I_{s}$ の 算定には準定常状態線 (QSSL) と最もゆるい状態での間 隙比が必要である. 定常状態は各試験のピーク強度時ま たは最終状態とし, 準定常状態は定常状態と同じである と仮定した。また， $e_{0}$ は最大間隙比試験で得られた $e_{\text {max }}$ としている．Fig. 7 および 8 より，OCR ${ }^{*}$ と $\psi$ および $I_{s}$ の相関性は非常に高く, 線形関係が成り立つことがわか る. 今回の佐原砂の場合, 式 (16)の材料パラメータを $\alpha$ $=0.991, \beta=0.649$ とすることで, $I_{s}$ は $O C R^{*}$ と関連づけ られる． $I_{s}$ は砂の締固め度合いを表わすため， $I_{s}$ に応心゙ て異なる砂の締固め効果は，OCR て本論文の弾塑性構成式で表現できることが示された。

$$
4 \text { おわりに }
$$

締固めによる改良効果は, 密度の増加（間隙比の減少） と平均有効応力の増加で表されるが，その両者の効果を 考慮するには，状態指数 $I_{s}$ 等を用いることが有効である. $I_{s}$ を弾塑性構成式に含まれるパラメータ $\left(M_{m}^{*}\right.$ あるいは $\left.O C R^{*}\right)$ と関連づけることにより，締固め砂質地盤の挙動 を説明することが可能であることがわかった。 今後は,

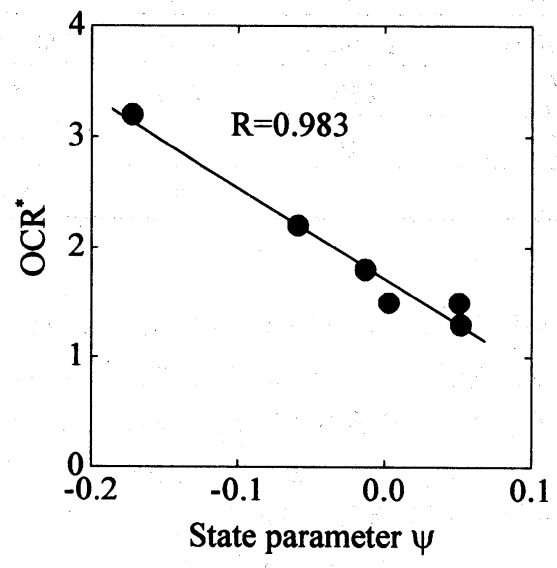

Fig. 8. $O C R^{*} \sim \psi$ ralation.

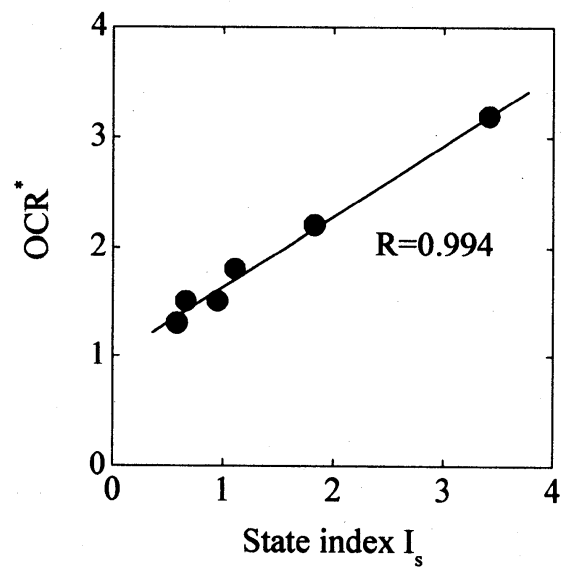

Fig. 9. $O C R^{*} \sim I_{s}$ ralation. 
Table III. Material parameters.

Before compaction $\left(e_{0}=0.95\right)$

\begin{tabular}{cccc}
\hline$e$ & 0.925 & 0.895 & 0.845 \\
\hline$\sigma_{m 0}^{\prime}(\mathrm{kPa})$ & 49.1 & 96.1 & 196.2 \\
\hline$\lambda$ & 0.0567 & 0.0567 & 0.0567 \\
\hline$\kappa$ & 0.0091 & 0.0091 & 0.0091 \\
\hline$M_{f}^{*}$ & 1.190 & 1.190 & 1.190 \\
\hline$M_{m}^{*}$ & 1.170 & 1.170 & 1.170 \\
\hline$\sigma_{m b}^{\prime}(\mathrm{kPa})$ & 108.0 & 144.1 & 255.1 \\
\hline$O C R^{*}$ & 2.2 & 1.5 & 2.2 \\
\hline$E(\mathrm{kPa})$ & 16,000 & 26,500 & 38,000 \\
\hline$G_{\max }^{P}$ & 150 & 150 & 150 \\
\hline$G_{\min }^{P}$ & 10 & 10 & 10 \\
\hline$C_{f}$ & 40 & 40 & 40 \\
\hline
\end{tabular}

After compaction $\left(e_{0}=0.80\right)\left(a_{s}=10 \%\right)$

\begin{tabular}{cccc}
\hline$e$ & 0.812 & 0.787 & 0.749 \\
\hline$\sigma_{m 0}^{\prime}(\mathrm{kPa})$ & 49.1 & 186.4 & 392.4 \\
\hline$\lambda$ & 0.0359 & 0.0359 & 0.0359 \\
\hline$\kappa$ & 0.0082 & 0.0082 & 0.0082 \\
\hline$M_{f}^{*}$ & 1.190 & 1.190 & 1.190 \\
\hline$M_{m}^{*}$ & 1.150 & 1.150 & 1.150 \\
\hline$\sigma_{m b}^{\prime}(\mathrm{kPa})$ & 157.1 & 335.5 & 588.6 \\
\hline$O C R^{*}$ & 3.2 & 1.8 & 1.5 \\
\hline$E(\mathrm{kPa})$ & 25,500 & 41,500 & 50,000 \\
\hline$G_{\max }^{P}$ & 250 & 250 & 250 \\
\hline$G_{\min }^{P}$ & 10 & 10 & 10 \\
\hline$C_{f}$ & 80 & 80 & 80 \\
\hline
\end{tabular}

等方的な平均有効応力の増加の効果のみではなく, 未改 良地盤と改良地盤での $K_{0}$ 值の変化を考慮し, 異方圧密履 歴後の非排水せん断試験およびそれらのシミュレーション を実施するなどして, より広範な有効応力状態での弾塑 性構成式の適用性を検討する必要がある。さらに, 弾塑 性構成式を有効応力液状化解析へ組み込み, 而震性能の 評価を行うことを念頭において, 繰返し載荷時の締固め 砂質地盤の材料パラメータの設定方法についても詳細に 検討を行う必要がある。
Table IV. State parameter and state index.

Before compaction $\left(e_{0}=0.95\right)$

\begin{tabular}{cccc}
\hline$e$ & 0.925 & 0.895 & 0.845 \\
\hline$\sigma_{m 0}{ }^{\prime}(\mathrm{kPa})$ & 49.1 & 96.1 & 196.2 \\
\hline$\sigma_{m b}^{\prime}(\mathrm{kPa})$ & 108.0 & 144.1 & 255.1 \\
\hline$O C R^{*}$ & 2.2 & 1.5 & 2.2 \\
\hline$\psi$ & -0.059 & 0.003 & 0.052 \\
\hline$I_{s}$ & 1.831 & 0.950 & 0.581 \\
\hline \multicolumn{4}{c}{} \\
\hline \multicolumn{4}{c}{ After compaction $\left(e_{0}=0.80\right)\left(a_{s}=10 \%\right)$} \\
\hline$\sigma_{m 0}^{\prime}(\mathrm{kPa})$ & 0.812 & 0.787 & 0.749 \\
\hline$\sigma_{m b}^{\prime}(\mathrm{kPa})$ & 49.1 & 186.4 & 392.4 \\
\hline$O C R^{*}$ & 157.1 & 335.5 & 588.6 \\
\hline$\psi$ & 3.2 & 1.8 & 1.5 \\
\hline$I_{s}$ & 3.423 & 1.107 & 0.660 \\
\hline
\end{tabular}

参 考 文 献

1) 山本 実, 野津光夫, 山田 隆, 子飼喜弘, 第 32 回地盤 工学研究発表会講演概要集, 2317 (1997).

2 ) 山本 実, 地質と調査, 9 (1997).

3 ) 山本 実, 原田健二, 野津光夫, 大林 淳, 第 32 回地盤 工学研究発表会講演講演集, 2631 (1997).

4) 原田健二, 山本 実, 大林 淳, 土木学会第 53 回年次学 術講演会講演概要集, III-B, 544 (1998).

5 ) 三輪 滋, 小堤 治, 安田進, 森浩章, 第 35 回地盤 工学研究発表会講演講演集, 2419 (2000).

6 ) F. Oka, A. Yashima, T. Shibata, M. Kato and R. Uzuoka, Applied Scientific Research, 52, 209 (1994).

7 ) F.Oka, A.Yashima,Y.Taguchiand S.Yamashita, Geotechnique, 49, 661 (1999).

$8)$ K. Been and M. G. Jefferies, Geotechnique, 35, 99 (1985).

9) K. Ishihara, Geotechnique, 43, 351 (1993).

10) G. Castro, "Liquefaction of Sand", Ph. D. thesis, Dvision of Engineering and Applied physics, Harvard University (1975).

11) T.Adachi and F.Oka, Results of Int. Workshop on Constitutive Relations for sand, 141 (1982). 